\title{
TOTAL QUALITY MANAGEMENT (TQM) DALAM PENDIDIKAN
}

\section{Suto Prabowo}

\begin{abstract}
Abstrak
Peningkatan mutu pendidikan harus ditingkatkan terus menerus dan berkesinambungan. Total Quality Management adalah salah satu model atau metode yang digunakan untuk meningkatkan mutu pendidikan di lembaga pendidikan. Total Quality Management merupakan salah satu kunci keberhasilan tujuan pendidikan yang paling efektif. Karena TQM mengedepankan integrasi dari semua fungsi dan proses serta memberdayakan dan melibatkan semua unsur yang ada di lemabaga pendidikan tersebut. TQM harus diberlakukan terus menerus dan berkesinambungan demi tercapainya tujuan pendidikan, yang memberikan kepuasan kepada peserta didik, orang tua dan masyarakat.
\end{abstract}

Kata Kunci: Total Quality Management, meningkatkan Mutu Pendidikan

Manajemen merupakan salah satu kunci keberhasilan suatu organisasi dalam mencapai suatu tujuan. Perhatian ilmu manajemen terhadap peningkatan mutru suatu produk dalam dua dasa warsa ini meningkat pesat. Perkembangannya dimulai dari dunia industri dan dianggap berhasil meningkatkan efisiensi dan penjualan produk industri itu. Keberhasilan itu merambah ke setiap kegiatan yang menggunakan managemen untuk meningkatkan kinerja organisasi usaha atau perusahaan. Salah satu bentuk manajemen yang berupaya untuk meningkatkan dan mempertahankan kualitas atau mutu industri tersebut adalah total quality management (TQM) yang diterjemahkan ke dalam bahasa Indonesia menjadi manajemen kendali mutu ada pula yang mengatakannya Manajemen Peningkatan Mutu (MPM).

TQM sebenarnya di kembangkan dari pemikiran sistem thingking, yang juga di mulai dari dunia industri yang selanjutnya di jabarkan dan di aplikasikan menjadi TQM di dunia pendidikan. Manajemen peningkatan mutu yang di kembangkan di dunia pendidikan ini merupakan suatu model yang di aplikasikan berdasarkan prinsip sistem Thingking yang menekankan bahwa segala sesuatu

jsh Jurnal Sosial Humaniora, Vol 5 No.1, Juni 2012 
harus di lihat dalam prespektif kebutuhan yang di padukan dengan Quality Assurance yang di kembangkan di Australia.

Ross (1995) mendefinisikan TQM sebagai integrasi dari semua fungsi dan proses dalam organisasi untuk memperoleh dan mencapai perbaikan serta perbaikan peningkatan kualitas barang sebagai produk dan layanan yang berkesinambungan. Tujuan utamanya adalah kepuasan konsumen atau pelanggan. Karena acuannya adalah bidang ekonomi, perdagangan dan perusahaan, maka kendali mutu merupakan hal yang sangat mendasar dalam menjamin persaingan pasar global. Selanjutnya konsep TQM atau MPM didasarkan atas sejumlah gagasan itu berarti bahwa memikirkan kualitas atau mutu harus dilihat dari berbagai fungsi perusahaan yang di mulai dari proses awal sampai akhir proses yang mengintegrasikan berbagai fungsi yang saling berhubungan pada semua tindakan. Demikian juga dalam dunia pendidikan.

Hal itu merupakan pendekatan sistem yang menganggap bahwa setiap interaksi harus terjadi antara berbagai unsur dalam organisasi. Dengan demikian keefektifan yang utuh dari sistem akan lebih tinggi dari pada jumlah masingmasing hasil sub sistem secara sendiri-sendiri.

Di bidang pendidikan manajenen peningkatan mutu dapat di definisikan sebagai sekumpulan prinsip atau teknik yang menekankan bahwa peningkatan mutu harus bertumpu pada lembaga pendidikan untuk secara terus menerus dan berkesinambungan meningkatkan kapasitas dan kemampuan organisasinya guna memenuhi tuntutan dan kebutuhan peserta didik dan masyarakat. Di dalam MPM terkandung upaya:

1. Mengendalikan proses yang berlangsung di lembaga pendidikan atau sekolah baik kurikuler maupun administrasi.

2. Melibatkan proses diagnosis dan proses tindakan untuk menindak lanjuti diagnosis.

3. Peningkatan mutu harus di tingkatkan atas data dan fakta baik yang bersifat kualitatif maupun kwantitatif.

4. Peningkatan mutu harus di tingkatkan secara terus menerus dan berkesinambungan. 
5. Peningkatan mutu harus memberdayakan dan melibatkan semua unsur yang ada di lembaga pendidikan.

6. Peninfkatan mutu memiliki tujuan yang menyatakan bahwa sekolah dapat memberikan kepuasan kepada peserta didik, orang tua dan masyarakat.

\section{Gagasan Sentral terhadap Peningkatan Mutu Pendidikan}

Aplikasi MPM terhadap sekolah didasarkan atas pemikiran bahwa pada administrator dan manajer pendidikan perlu menemukan kerangka kerja yang muncul dari dalam lembaga pendidikan itu sendiri, yang diperkirakan dapat menopang mutu dan kinerja sekolah dan lembaga pendidikan yang menjadi tanggung jawab mereka. Morgan dan Murgatroyd (1994) mengemukakan empat gagasan dasar yang sangat sentral bagi keefektifan sistem persekolahan.

Pertama adalah bahwa lembaga pendidikan merupakan mata rantai yang menghubungkan pelanggan (Customer, Klien) dan pemasok (Supplier). Sekolah dalam realitanya adalah suatu organisasi yang mengendalikan mata rantai para klien. Para guru adalah pemasok layanan terhadap peserta didik dan para orang tua, pemerintah merupakan pemasok layanan terhadap guru, administrator sekolah adalah pemasok layanan kepada guru dan para guru memberikan layanan satu terhadap yang lain. Ada pelanggan internal ialah mereka yang bekerja untuk sekolah dan ada pula pelangan eksternal ialah mereka yang mempunyai tuntutan atau kepentingan layanan dari sekolah.

Kedua, yang merupakan gagasan kunci adalah bahwa semua hubungan antara pelanggan dan pemasok apakah itu internal maupun eksternal ditengahi oleh proses. Guru yang menyelenggarakan kesempatan belajar kepada peserta didik, staf tata usaha yang menyediakan layanan kepentingan atau administrator yang merancang jadwal kegiatan tahunan sekolah, semuanya itu merupakan rangkaian manajemen proses. Mutu atau kualitas diproses melalui perbaikan proses yang diharapkan mampu mendukung hasil-hasil yang berbeda dari proses tersebut.

Ketiga, orang yang paling dapat melakukan perbaikan proses adalah mereka yang dekat dengan pelanggan dalam proses tersebut. Pernyataan itu harus 
dilihat sebagai implikasi yang agak radikal terhadap pengawas, manajemen dan desain sekolah sebagai suatu organisasi.

Keempat, pemandangan yang dianggap agak radikal bagi kebanyakan manajer yang diangkat disekolah, yaitu perasaan bahwa mereka ditunjuk untuk memimpin organisasi. Dalam alur organisasi semua harus melapor dan bertanggung jawab kepada mereka. Karena itu adalah hal yang sangat krisis diperankan dalam peranan kepemimpinan semacam itu disekolah. Hal penting yang perlu dikemukakan disini adalah bahwa kepemimpinan bagi visi, mutu dan performansi, serta kepemimpinan untuk pengawasan merupakan dua hal yang sangat berbeda di dalam pelaksanaannya. Untuk menjamin terhadapnya dukungan perbaikan performansi kualitas terhadap sekolah dipersyaratkan kepemimpinan yang bervisi, yang mendukung meningkatkan kinerja terhadap mereka yang dekat (familier) dengan klien.

\section{Beberapa Komponen Penunjang Manajemen Peningkatan Mutu}

Manajemen peningkatan mutu mempersyaratkan integrasi dari berbagai faktor yaitu faktor klien atau pelanggan, kepemimpinan, tim, proses dan struktur.

Pelanggan atau klien. Dalam organisasi MPM pelanggan adalah seseorang atau kelompok yang menerima produk atau jasa layanan. Jadi klien tidak berada secara external terhadap organisasi tetapi berada pada setiap tahapan yang mempersyaratkan penyempurnaan hasil sebuah produk atau pemberian layanan. Hal ini menggambarkan bahwa terhadap mata rantai dari klien yang keterkaitannya bersama dengan proses.

Kepemimpinan. Jika integritas moral merupakan hal yang fondamental bagi MPM, maka kepemimpinan merupakan cara mengerjakannya. Kepemimpinan dalam konteks MPM adalah menetapkan dan mengendalikan visi. MPM secara tajam menggambarkan perbedaan memimpin, memanage dan mengadministrasikan. Pemimpin dalam MPM pada dasarnya peduli dengan nilainilai dan orang, menetapkan arah dan mengijinkan orang untuk mencapai target yang berhubungan dengan hal makro maupun mikro. 
Tim. Sebuah tim merupakan kualitas kelompok. Hampir semua keputusan menekankan pentingnya kejelasan tujuan dan hubungan interpersonal yang efektif bagai dasar terjadinya kerja kelompok yang efektif. Baik secara teoritik maupun praktik tim di pandang sebagai hal yang fondamental terhadap manajemen mutu dalam organisasi.

Proses. Kunci penting dalam manajemen mutu adalah menetapkan komponen proses kerja. Pada dasarnya, sekali klien menetapkan persyaratan yang telah di sepakati, maka hal penting untuk dilakukan adalah menetapkan proses dan prosedur yang menjamin kesesuaiannya dengan persyaratan.

Struktur. Organisasi yang mencoba memperkenalkan MPM tanpa meninjau strukturnya mungkin akan menghadapi kegagalan. Beberapa organisasi memiliki struktur yang berfokus pada klien cenderung mendasarkan diri pada hirarki formal sekaligus membatasi kerja praktis yang birokratik. Misalnya organisasi memiliki kedekatan secara utuh dengan klien, pemasok berbicara dengan klien.

Keberhasilan MPM suatu organisasi seharusnya melahirkan rasa kebanggan dan kesempatan untuk berkembang bagi orang-orang didalamnya (staf dan klien) sehingga mereka merasa sebagai pemilik atau ikut memiliki, perwujudan tujuan suatu organisasi bersama dan di antara semua karyawan. Komitmen berarti juga keterlibatan menanggung akibat dalam pencapaian tujuan, menurut kerja yang sistematis, meneruskan informasi mengenai adanya kesempatan untuk melakukan inovasi dan pengembangan. Komitmen sifatnya normatif.

Komunikasi di antara anggota tim memiliki kekuatan, walaupun sederhana tetapi efektif, komunikasi harus didasarkan pada kenyataan dan pengertian yang murni, bukanyaasumsi apalagi yang sifatnya humor. Komunikasi memiliki alur yang bebas dalam organisasi.

Kesimpulan

Manajemen Peningkatan Mutru (MPM) atau Total Quality Management (TQM) walaupun agak bersifat filosofis, mengandung makna prinsip mendasar 
yang mengarahkan peningkatan organisasi secara berkelanjutan. MPM merupakan aplikasi metode kuantitatif dan sumber daya manusia untuk meningkatkan semua aspek organisasi dan mengarah pada terpenuhinya kebutuhan klien atau pelanggan, saat ini dan untuk yang akan dating MPM mengintegrasikan teknikteknik manajemen yang mendasar, menghadirkan upaya-upaya peningkatan yang berkelanjutan. Pada era Globalisasi sekarang ini Manajemen Peningkatan Mutu (MPM) atau Total Quality Manajement (TQM) lebih efektif dalam memberdayakan dan meningkatkan mutu Pendidikan di Sekolah maupun di Perguruan Tinggi.

\section{Daftar Pustaka}

Bennet, N, Crawford, M. \& Riches, C. 1992. Managing Change in Education: Individual and Organization Perspectives. London: Paul Chapman Publishing Co.

Dikmenum Depdikbud 1999. Pelatihan Kepala Sekolah Menengah Umum, Suplemen 2: Manajemen Peningkatan Mutu. Jakarta: Depdikbud Hasan A. S. K. 1999. Penerapan Total Quality Management dan ISO 9000 dalam Pendidikan Teknik. Jurnal Ilmu Pendidikan, Jilid 6 Nomor 1, Februari 1999, hal. 3-20

Murgatroydand the School. Buckingham: Open University Press. S. \& Margon, C. 1994. Total Quality Management and the School. Buckingham: Open University Press

Universitas Kristen Petra. 1997. Total Quality Management untuk Pendidikan Tinggi. Makalah pada Seminar tentang TQM di Perguruan Tinggi. Surabaya: Universitas Kristen Petra. 
